\title{
Blueshift in $\mathrm{Mg}_{x} \mathrm{Zn}_{1-x} \mathrm{O}$ alloys: Nature of bandgap bowing
}

\author{
Almamun Ashrafi ${ }^{1, a)}$ and Yusaburo Segawa ${ }^{2}$ \\ ${ }^{1}$ Department of Electronic Materials Engineering, Research School of Physical Sciences and Engineering, \\ The Australian National University, Canberra 0200, Australia \\ ${ }^{2}$ Frontier Research System, Institute of Physical and Chemical Research, Wako 351-0198, Japan
}

(Received 30 July 2008; accepted 7 November 2008; published online 23 December 2008)

\begin{abstract}
A $\mathrm{Mg}$ composition-dependent blueshift has been studied in $\mathrm{Mg}_{x} \mathrm{Zn}_{1-x} \mathrm{O}$ alloys deposited on $6 H$-SiC(0001) substrates. The localized exciton energy in $\mathrm{Mg}_{x} \mathrm{Zn}_{1-x} \mathrm{O}$ alloys for $x \sim 0.3$ was blueshifted in the range $212-248 \mathrm{meV}$. The large negative bowing parameter was estimated in $\mathrm{Mg}_{x} \mathrm{Zn}_{1-x} \mathrm{O}$ alloys to be $4.72 \pm 0.84 \mathrm{eV}$. This large bandgap bowing emphasizes the Stokes shift, which has been attributed to the existence of spontaneous polarization effects due to the polar growth of $\mathrm{Mg}_{x} \mathrm{Zn}_{1-x} \mathrm{O} / \mathrm{SiC}$ heterostructure and local compositional inhomogeneity. (C) 2008 American Institute of Physics. [DOI: 10.1063/1.3050338]
\end{abstract}

\section{INTRODUCTION}

Wurtzite ( $\mathrm{Mg}, \mathrm{Zn}, \mathrm{Be}, \mathrm{Cd}) \mathrm{O}$ materials provide enormous practical benefits as promising candidates for the use of exciton-based laser diodes, light emitting diodes, and optical sensors/detectors operating in the visible to ultraviolet spectral regions due to their large bandgap energy covering from 2.24 to $7.60 \mathrm{eV}^{1,2}$ Experimental and theoretical studies have extensively been addressed to the extraordinary optical and transport properties of $(\mathrm{Mg}, \mathrm{Zn}, \mathrm{Cd}) \mathrm{O}$ materials relevant to such applications. ${ }^{1,2}$ However, practical applications and studies of $(\mathrm{Mg}, \mathrm{Zn}, \mathrm{Cd}) \mathrm{O}$ materials system are still a challenge, since the shallow thermodynamic solubility and disorder of atoms locally play a significant role in the $(\mathrm{Mg}, \mathrm{Zn}$, $\mathrm{Cd}) \mathrm{O}$ matrix. In consequence, the $\mathrm{Mg}_{x} \mathrm{Zn}_{1-x} \mathrm{O}$ heterostructure alloying is still immature and requires exclusive studies especially to clarify the solubility limit and the microscopic character of $\mathrm{Mg}$ atoms. The thermodynamic shallow solubility limit of $\mathrm{Mg}$ in $\mathrm{ZnO}$ has been reported of $12 \%,{ }^{3}$ primarily due to their structural dissimilarities as the $\mathrm{ZnO}$ and $\mathrm{MgO}$ materials are stable with wurtzite and rocksalt phases, respectively. This structural mismatch causes phase segregation triggered by the strain kinetics and finally limits the $\mathrm{Mg}$ incorporation into the $\mathrm{ZnO}$ matrix. ${ }^{1-3} \mathrm{~A}$ strong variation with $\mathrm{Mg}$ composition has been found for the fundamental energy gap of the $\mathrm{Mg}_{x} \mathrm{Zn}_{1-x} \mathrm{O}$ alloys. ${ }^{4}$ It has been expected that this is accompanied by a bandgap bowing and giant energy shift between the photoluminescence (PL) peaks and absorption edges, so-called Stokes shift. In addition, the microscopic polarization in the $\mathrm{Mg}_{x} \mathrm{Zn}_{1-x} \mathrm{O} / \mathrm{Al}_{2} \mathrm{O}_{3}$ heterointerface has a major influence on the design criteria of alloys that impact significantly to the optical and transport properties. ${ }^{3}$ Therefore, these complex limitations play the crucial roles in heteroepitaxy and degrade the crystalline quality.

Wurtzite $\mathrm{ZnO}$ has a direct bandgap energy of $3.37 \mathrm{eV}{ }^{1,2}$ corresponding to the near ultraviolet region of the spectrum. This bandgap energy can further be raised into the ultraviolet region by alloying with $\mathrm{MgO}\left(E_{g} \sim 5.20 \mathrm{eV}\right)$ or lowered into the visible/blue region by alloying with $\mathrm{CdO}$ material $\left(E_{g}\right.$

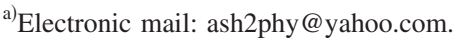

$\sim 2.24 \mathrm{eV}) .{ }^{2}$ To a first approximation, the bandgap energy engineering of any alloy, such as $\mathrm{Mg}_{x} \mathrm{Zn}_{1-x} \mathrm{O}$, can be tailored using the composition-weighted average of $\mathrm{ZnO}$ and $\mathrm{MgO}$ bandgaps, given by $E_{\mathrm{Mg}_{x} \mathrm{Zn}_{1-x} \mathrm{O}}(x)=x E_{\mathrm{MgO}}+(1-x) E_{\mathrm{ZnO}} \cdot \mathrm{A}$ more realistic description includes a nonlinear term given by $E_{\mathrm{Mg}_{x} \mathrm{Zn}_{1-x} \mathrm{O}}(x)=x E_{\mathrm{MgO}}+(1-x) E_{\mathrm{ZnO}}-\delta x(1-x)$, known as Vegard's law, where $\delta$ is known as the bandgap bowing parameter and $x$ is the $\mathrm{Mg}$ composition. Recently, our group has reported a routine determination of $\mathrm{Mg}$ composition in the $\mathrm{Mg}_{x} \mathrm{Zn}_{1-x} \mathrm{O}$ alloys by employing Vegard's law and a theoretical model within an error limit of $\sim 3 \%{ }^{4}$ In addition, it has been demonstrated that PL peak energies of $\mathrm{Mg}_{x} \mathrm{Zn}_{1-x} \mathrm{O}$ alloys do not comply with the conventional (downward parabolic) Vegard's law. ${ }^{4}$ In principle, parabolic (upward or downward) compositional dependence is assumed for the bandgap of alloys, where $\delta$ captures the magnitude of parabolic nonlinearity. ${ }^{5}$ To get a clear picture on this upward parabolic nature in $\mathrm{Mg}_{x} \mathrm{Zn}_{1-x} \mathrm{O}$ alloys deposited on $\mathrm{SiC}$ substrates, $\mathrm{PL}$, absorption $(\mathrm{AB})$, reflectance $(\mathrm{RF})$, and $\mathrm{x}$-ray diffraction (XRD) measurements were performed. The localized exciton energy $\left(E_{\mathrm{ex}}\right)$ of $\mathrm{Mg}_{x} \mathrm{Zn}_{1-x} \mathrm{O}$ alloys for $x \sim 0.30$ is blueshifted in the range $212-248 \mathrm{meV}$. A large bandgap bowing of $-4.72 \mathrm{eV}$ in the $\mathrm{Mg}_{x} \mathrm{Zn}_{1-x} \mathrm{O}$ alloys emphasizes the large Stokes shift, which has been attributed to the spontaneous polarization experienced in the heterointerfaces and compositional disorder of $\mathrm{Mg}$ atoms locally.

\section{EXPERIMENT}

$\mathrm{Mg}_{x} \mathrm{Zn}_{1-x} \mathrm{O}$ alloys were grown on $6 H-\mathrm{SiC}(0001)$ substrates by metalorganic chemical-vapor deposition. The substrate cleaning and processing have been described in detail elsewhere. ${ }^{4,6}$ The $\mathrm{Mg}_{x} \mathrm{Zn}_{1-x} \mathrm{O}$ alloys were deposited at the atmospheric pressure over the selected substrate temperature $\left(T_{g}\right)$ range of $400-600{ }^{\circ} \mathrm{C}$. Diethyl zinc (DEZn) and bismethyl cyclopentadienyl-magnesium $\left[(\mathrm{MeCp})_{2} \mathrm{Mg}\right]$ were allowed to flow for $\sim 20 \mathrm{~s}$ prior to the introduction of $\mathrm{O}_{2}$. During the deposition of $\mathrm{Mg}_{x} \mathrm{Zn}_{1-x} \mathrm{O}$ alloys, the flow rates of $(\mathrm{MeCp})_{2} \mathrm{Mg}$ and $\mathrm{O}_{2}$ were kept constant at 20 and $10 \mathrm{SCCM}$ (SCCM denotes cubic centimeter per minute at STP), respectively, while the flow rate of DEZn was varied from 0 to 12 


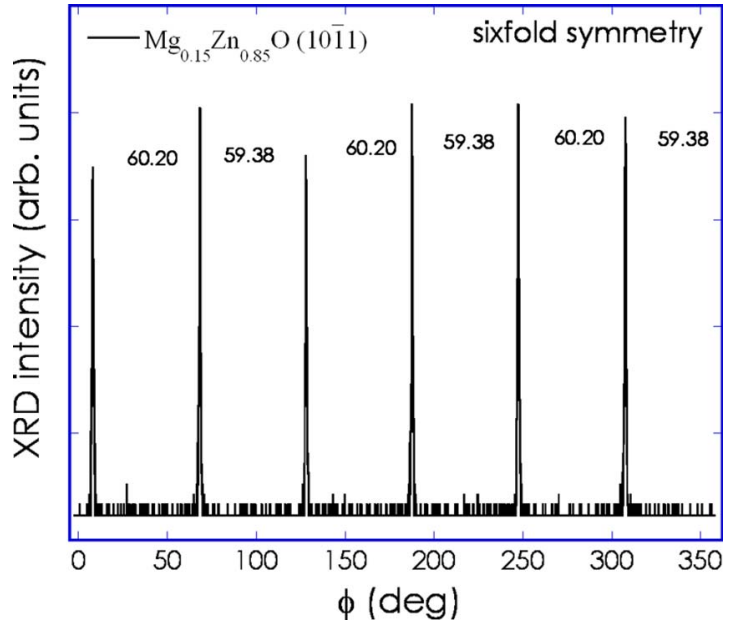

FIG. 1. (Color online) The $\varphi$-scan of $\mathrm{Mg}_{0.15} \mathrm{Zn}_{0.85} \mathrm{O}\{10 \overline{1} 1\}$ alloy deposited on $\mathrm{SiC}(0001)$ substrate, indicating the sixfold symmetry with polar growth along the $c$ axis. The typical $\mathrm{Mg}_{x} \mathrm{Zn}_{1-x} \mathrm{O}$ layer thickness was $0.75 \mu \mathrm{m}$.

SCCM. The $\operatorname{Mg}_{x} \mathrm{Zn}_{1-x} \mathrm{O}$ alloys have been characterized by $\varphi$ scan using the four-circle diffractometer: XRD, PL, RF, and $\mathrm{AB}$ measurements. ${ }^{7}$ The typical $\mathrm{Mg}_{x} \mathrm{Zn}_{1-x} \mathrm{O}$ layer thickness was $0.75 \mu \mathrm{m}$. Calculation of $\mathrm{Zn}$ and $\mathrm{Mg}$ composition in the $\mathrm{Mg}_{x} \mathrm{Zn}_{1-x} \mathrm{O}$ alloys has been reported in Ref. 4 .

\section{RESULTS AND DISCUSSION}

Figure 1 shows the $\varphi$ scan of $\mathrm{Mg}_{0.15} \mathrm{Zn}_{0.85} \mathrm{O}\{10 \overline{1} 1\}$ planes, which clearly display a sixfold crystal symmetry. This observation conclusively reveals a hexagonal structure of $\mathrm{Mg}_{x} \mathrm{Zn}_{1-x} \mathrm{O}$ alloys grown on $\mathrm{SiC}$ substrates. An epitaxial relationship in the $\mathrm{Mg}_{x} \mathrm{Zn}_{1-x} \mathrm{O} / \mathrm{SiC}$ heterostructures was found to be $(\mathbf{1 1 2 0})_{\mathrm{Mg}_{x} \mathrm{Zn}_{1-x} \mathrm{O}} \|(\mathbf{1 1 2 0})_{\mathrm{SiC}}$ and $(\mathbf{0 0 0 1})_{\mathrm{Mg}_{x} \mathrm{Zn}_{1-x} \mathrm{O}} \|(\mathbf{0 0 0 1})_{\mathrm{SiC}}$. These results obviously indicate the polar growth, i.e., the $\mathrm{Mg}_{x} \mathrm{Zn}_{1-x} \mathrm{O}$ alloys grow along the $c$ axis. The calculated lattice constants of $a$ and $c$ axis lengths of $\mathrm{Mg}_{x} \mathrm{Zn}_{1-x} \mathrm{O}$ alloys by the $c / a$ ratio as a function of $\mathrm{Mg}$ content have been plotted in Fig. 2(a). For comparison, the c/a ratio of $\mathrm{Mg}_{x} \mathrm{Zn}_{1-x} \mathrm{O}$ alloys grown on $\mathrm{Al}_{2} \mathrm{O}_{3}$ substrates has been plotted together with those of the $\mathrm{Mg}_{x} \mathrm{Zn}_{1-x} \mathrm{O} / \mathrm{SiC}$ heterostructure, cited from Ref. 8. This shows that the $c / a$ ratio decreases monotonically from 1.602 to 1.575 until the $\mathrm{Mg}$ composition reaches $34 \%$ with the increase in $\mathrm{Mg}$ content in both the heterostructures. This observation clearly indicates that the $c / a$ ratio does not decrease further since the cell volume reaches a constant value. In principle, incorporation of $\mathrm{Mg}$ into the wurtzite $\mathrm{ZnO}$ structure expands the unit cell resulting in a total volume expansion. These results suggest that the phase segregation may about to start in the $\mathrm{Mg}_{x} \mathrm{Zn}_{1-x} \mathrm{O}$ alloys for $x \geq 34 \%$, which agrees well with the $\mathrm{Mg}_{x} \mathrm{Zn}_{1-x} \mathrm{O} / \mathrm{Al}_{2} \mathrm{O}_{3}$ heterostructure. ${ }^{4,6,8}$ Therefore, we will deal the blueshift and bandgap bowing in $\mathrm{Mg}_{x} \mathrm{Zn}_{1-x} \mathrm{O}$ alloys for the Mg composition of $x<34 \%$.

The thermodynamic instability/stability of $\mathrm{Mg}$ content in the $\mathrm{Mg}_{x} \mathrm{Zn}_{1-x} \mathrm{O}$ alloys has been studied by $T_{g}$ dependence growth and the subsequent postgrowth annealing. For the $T_{g}$ dependent $\mathrm{Mg}_{x} \mathrm{Zn}_{1-x} \mathrm{O}$ alloys, $\mathrm{Mg}$ flow rate was kept constant for 20 SCCM. Figure 2(b) shows that with the increase in $T_{g}, \mathrm{Mg}$ content increases due to the relatively faster de-
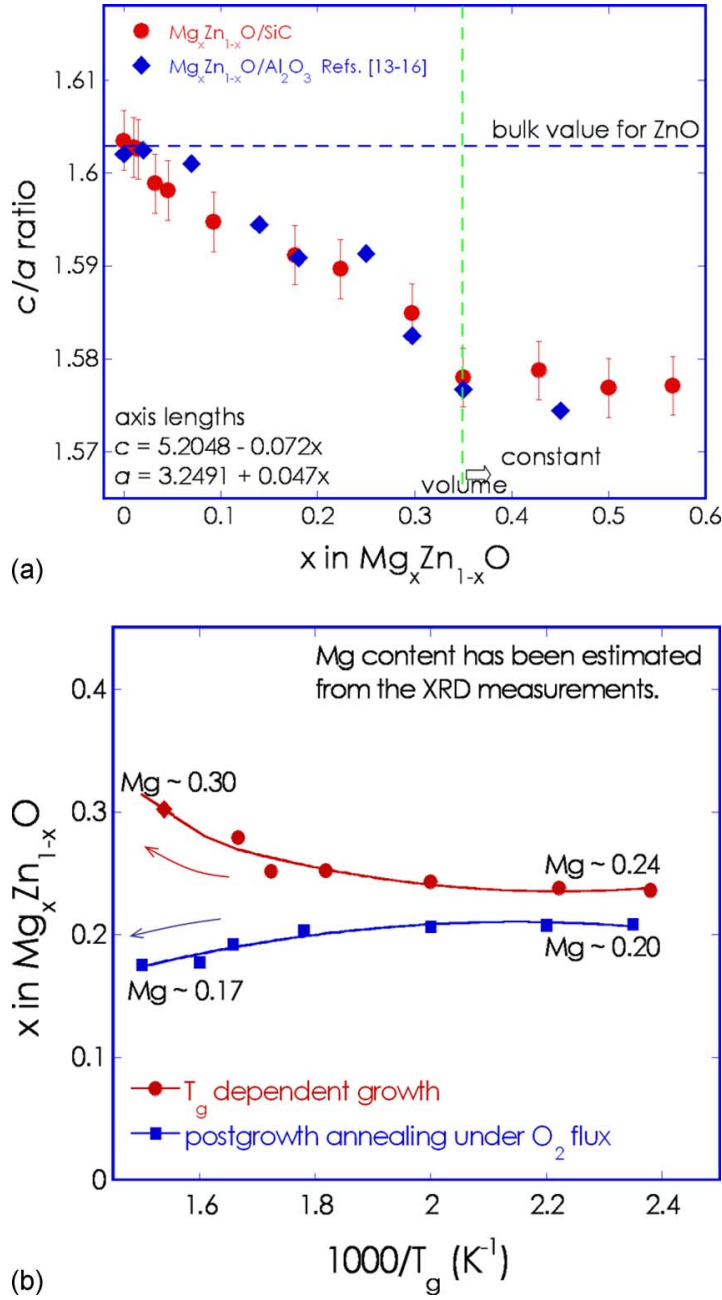

FIG. 2. (Color online) The (a) $c / a$ ratio and (b) deposition and postgrowth annealing temperature-dependent $\left(T_{g}\right) \mathrm{Mg}_{x} \mathrm{Zn}_{1-x} \mathrm{O}$ alloys as a function of $\mathrm{Mg}$ composition. The postgrowth annealing was done for $30 \mathrm{~min}$ under the $\mathrm{O}_{2}$ flux at the atmospheric pressure.

crease in sticking coefficient of $\mathrm{Zn}$ species, due to their different vapor pressures. It has been reported that the vapor pressure of $\mathrm{Zn}$ species is higher than that of the $\mathrm{Mg}(\mathrm{Zn}$ $>\mathrm{Mg}){ }^{8}$ suggesting that $\mathrm{Zn}$ might preferentially desorb from the growing surface, leaving the Mg-rich solid phase. To explore this character, postgrown $\mathrm{Mg}_{x} \mathrm{Zn}_{1-x} \mathrm{O}$ alloys were annealed at different temperatures inside a furnace under the $\mathrm{O}_{2}$ ambient. Figure 2(b) shows that with the increase in annealing temperature for $\mathrm{Mg}_{x} \mathrm{Zn}_{1-x} \mathrm{O}$ alloys, the $\mathrm{Mg}$ content decreases, clearly contradicting with the suggested $T_{g}$-dependent growth. As the postgrowth annealing was done under the atmospheric pressure, it is expected that even under the $\mathrm{O}_{2}$ ambient, the $\mathrm{Mg}_{x} \mathrm{Zn}_{1-x} \mathrm{O}$ alloys may be with the $\mathrm{Zn}$-rich rather than the $\mathrm{Mg}$-rich conditions. It is true that under the same growth conditions, growth rate of $\mathrm{ZnO}$ epilayer is faster than that of the $\mathrm{MgO}$ thin films. However, to clarify this thermal behavior and control the solid composition in $\mathrm{Mg}_{x} \mathrm{Zn}_{1-x} \mathrm{O}$ alloys under the postgrowth annealing, further investigations are necessary.

Figure 3(a) shows the optical responses of $\mathrm{ZnO}$ epilayers at 3.301, 3.332, and $3.331 \mathrm{eV}$ in the PL, RF, and AB spectra, respectively. The PL spectrum of $\mathrm{ZnO}$ epilayers exhibited a 


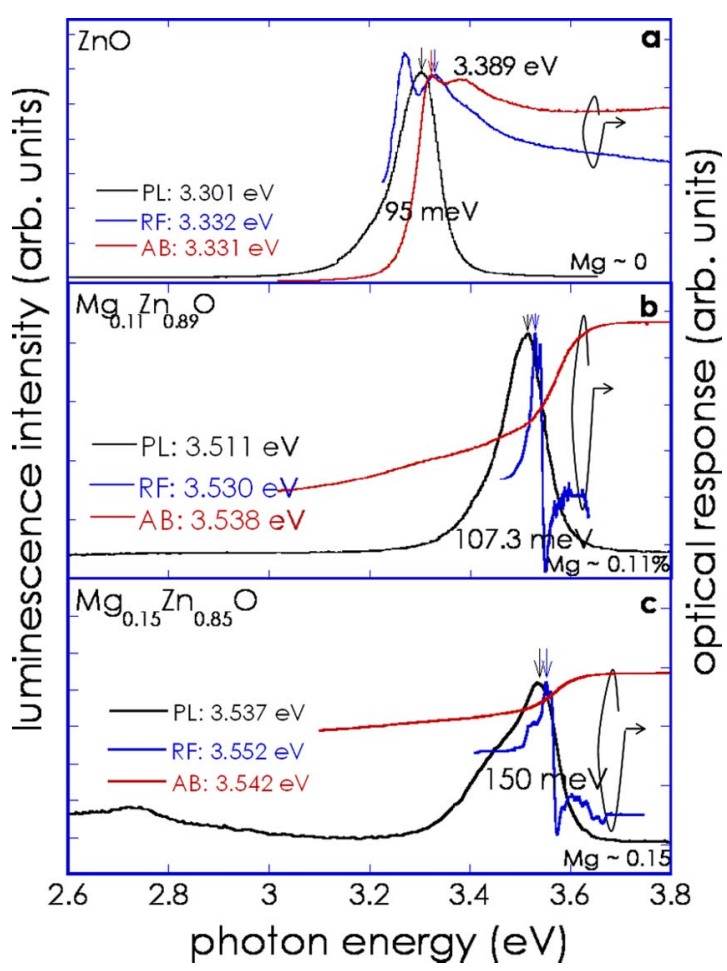

FIG. 3. (Color online) Optical properties of (a) $\mathrm{ZnO}$, (b) $\mathrm{Mg}_{0.11} \mathrm{Zn}_{0.89} \mathrm{O}$, and (c) $\mathrm{Mg}_{0.15} \mathrm{Zn}_{0.85} \mathrm{O}$ layers studied by PL, RF, and $\mathrm{AB}$ measurements. The full width at half maximum of the respective epilayers has been marked, which clearly increases with the increase in $\mathrm{Mg}$ content in the $\mathrm{Mg}_{x} \mathrm{Zn}_{1-x} \mathrm{O}$ alloys.

predominant near bandedge emission at $3.30 \mathrm{eV}$. The PL peak is assigned as being due to the recombination of excitons bound to certain impurities or defects. ${ }^{1,4}$ The $A$-exciton transition is clearly observed in the RF and $\mathrm{AB}$ spectra $(3.331 \mathrm{eV})$, with the $B$-exciton peak $(3.389 \mathrm{eV})$ visible at room temperature. Figures 3(b) and 3(c) show the systematic $\mathrm{Mg}$ composition-dependent optical properties of $\mathrm{Mg}_{x} \mathrm{Zn}_{1-x} \mathrm{O}$ layers deposited on $\mathrm{SiC}$. Throughout the experiments, the $E_{\mathrm{ex}}$ of $\mathrm{Mg}_{x} \mathrm{Zn}_{1-x} \mathrm{O}$ alloys were dominant in the optical spectra. The PL spectra of $\mathrm{Mg}_{0.11} \mathrm{Zn}_{0.89} \mathrm{O}$ and $\mathrm{Mg}_{0.15} \mathrm{Zn}_{0.85} \mathrm{O}$ alloys exhibited predominantly the $E_{\mathrm{ex}}$ emissions at 3.511 and $3.537 \mathrm{eV}$, respectively. The absorption edges of the $\mathrm{Mg}_{0.11} \mathrm{Zn}_{0.89} \mathrm{O}$ and $\mathrm{Mg}_{0.15} \mathrm{Zn}_{0.85} \mathrm{O}$ layers were recorded to be 3.538 and $3.542 \mathrm{eV}$, while the excitonic transitions in the RF spectra were 3.530 and $3.552 \mathrm{eV}$, respectively. The $E_{\text {ex }}$ values obtained for the $\mathrm{Mg}_{x} \mathrm{Zn}_{1-x} \mathrm{O}$ epilayers $(3.30-3.54 \mathrm{eV}$ for $x=0-0.20)$ are larger than that of the binary $\mathrm{ZnO}$ layers, and are comparable to that reported for the $\mathrm{Mg}_{x} \mathrm{Zn}_{1-x} \mathrm{O}$ alloys deposited on $\mathrm{Al}_{2} \mathrm{O}_{3}$ substrates. ${ }^{4,8}$ Although there are some energy differences among the PL, RF, and AB spectra, these results are broadly indicative of the compositional inhomogeneity, generally referred to as the Stokes shift.

Figure 4 shows the experimental $E_{\text {ex }}$ and Stokes shift of $\mathrm{Mg}_{x} \mathrm{Zn}_{1-x} \mathrm{O}$ alloys as a function of $\mathrm{Mg}$ content. The $E_{\mathrm{ex}}$ increases with the increase in $\mathrm{Mg}$ content in $\mathrm{Mg}_{x} \mathrm{Zn}_{1-x} \mathrm{O}$ alloys for $x \leq 0.2$ by $212-248 \mathrm{meV}$. However, the rate of change of $E_{\text {ex }}$ in the $\mathrm{Mg}_{x} \mathrm{Zn}_{1-x} \mathrm{O}$ layers due to $\mathrm{Mg}$ composition is different from the III-N materials. ${ }^{9}$ The III-N alloys follow the downward parabola, while the $\mathrm{Mg}_{x} \mathrm{Zn}_{1-x} \mathrm{O}$ alloy follows the upward parabola of Vegard's law. The $E_{\text {ex }}$ increases with the upward bowing in the $\mathrm{Mg}_{x} \mathrm{Zn}_{1-x} \mathrm{O}$ layers similarly to the

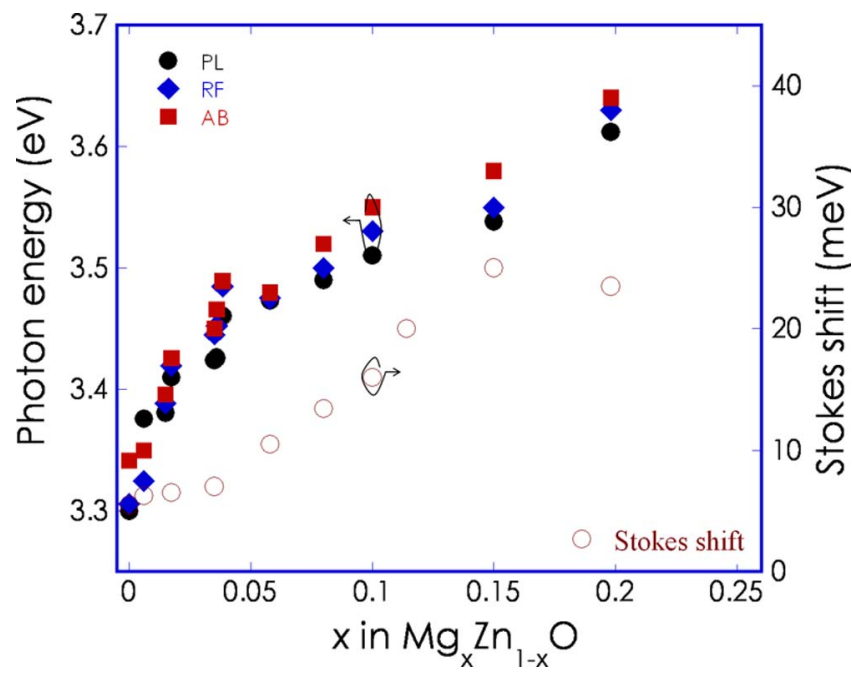

FIG. 4. (Color online) The PL (๑), RF ( ), and AB (ם) energies and Stokes shift $(\mathrm{O})$ in $\mathrm{Mg}_{x} \mathrm{Zn}_{1-x} \mathrm{O}$ alloys as a function of $\mathrm{Mg}$ composition.

other results demonstrated in the $\mathrm{Mg}_{x} \mathrm{Zn}_{1-x} \mathrm{O}$ alloys. ${ }^{1,2,4-6}$ In principle, the negative bowing parameter emphasizes an upward bowing due to defects or impurities and/or compositional inhomogeneity in the $(\mathrm{Mg}, \mathrm{Zn}) \mathrm{O}$ matrix. These parameters emphasize the large Stokes shift that has been recorded to be $\sim 30 \mathrm{meV}$ in the optical bands as shown in Fig. 4 .

Although an upward bandgap bowing tendency of the $E_{\text {ex }}$ in $\mathrm{Mg}_{x} \mathrm{Zn}_{1-x} \mathrm{O}$ alloys was obtained, there is no experimental evidence of this bowing parameter, $\delta$, in literature. In this work, we have estimated $\delta$ by a different approach than the conventional Vegard's law. ${ }^{10}$ It has been demonstrated that regardless of the alloy structure and composition, the spontaneous polarization always shows an upward bowing. ${ }^{11}$ In this context, the accuracy of $\delta$ is limited by two main factors: composition and PL energy position fluctuations at room temperature. We assume that both of these factors have the same influence on the experimental accuracy. The compositional inhomogeneity, $\Delta x$, can then be estimated by employing $\Delta x=\Delta c /\left(c_{\mathrm{ZnO}}-c_{\mathrm{MgO}}\right)$, where $\Delta c$ is the $\mathrm{x}$-ray linewidth $(\Delta \omega)$ for $x=0-0.30$ in the lattice constant unit, and $c_{\mathrm{ZnO}}$ and $c_{\mathrm{MgO}}$ are the bulk lattice constants. ${ }^{4}$ Using this equation, $\Delta x$ has been estimated to be 3.78 (angular to linear scale conversion has been done by using the relation $L=R \theta$, where $R$ is the atomic radius of $\mathrm{ZnO}$ material of $0.18 \mathrm{~nm}$ ). Similarly, if we assume that the PL peak energy increases primarily from the compositional fluctuations, then $\delta$ can be estimated by ${ }^{10,11}$

$$
\Delta x \cong \Delta E_{\mathrm{PL}} /\left|E_{\mathrm{ZnO}}-E_{\mathrm{MgO}}-\delta+2 x \delta\right|,
$$

where $\Delta E_{\mathrm{PL}}$ is the blueshifted energy in $\mathrm{Mg}_{x} \mathrm{Zn}_{1-x} \mathrm{O}$ alloys for $x=0-0.3$. From this equation, $\delta$ has been estimated with to be $-4.72 \mathrm{eV}$; consistent with the upward bowing behavior. In principle, the uncertainty in energy emission measurements is $\Delta E \cong k_{\mathrm{B}} T$, which gives the $\delta$ measurement uncertainty of $\Delta \delta \geq 4 \Delta E_{\mathrm{PL}} \cong 0.84 \mathrm{eV}$. Thus the resultant $\delta$ in the $\mathrm{Mg}_{x} \mathrm{Zn}_{1-x} \mathrm{O}$ alloy for $x=0.3$ should be $-4.72 \pm 0.84 \mathrm{eV}$.

The existence of this larger negative bowing, together with the compositional fluctuations, can be described in a first principles approximation by a parabolic model involving 
TABLE I. The bowing parameter for the II-O alloys.

\begin{tabular}{lccc}
\hline \hline Alloy & $\begin{array}{c}\text { Composition } \\
(x)\end{array}$ & $\begin{array}{c}\text { Bandgap bowing } \\
\delta(\mathrm{eV})\end{array}$ & Ref. \\
\hline $\mathrm{Mg}_{x} \mathrm{Zn}_{1-x} \mathrm{O}$ & $0-0.30$ & -4.86 & This work \\
$\mathrm{Mg}_{x} \mathrm{Zn}_{1-x} \mathrm{O}$ & $0-1.00$ & 0.56 & $8^{\mathrm{a}}$ \\
$\mathrm{Mg}_{x} \mathrm{Zn}_{1-x} \mathrm{O}$ & $0-0.34$ & 1.34 & $8^{\mathrm{a}}$ \\
$\mathrm{Be}_{x} \mathrm{Zn}_{1-x} \mathrm{O}$ & $0-1.00$ & 5.60 & 13 \\
$\mathrm{Cd}_{x} \mathrm{Zn}_{1-x} \mathrm{O}$ & $0-0.50$ & 8.14 & 13 \\
$\mathrm{Cd}_{x} \mathrm{Zn}_{1-x} \mathrm{O}$ & $0-0.50$ & 5.93 & 12 \\
$\mathrm{ZnO}_{1-x} \mathrm{~S}_{x}$ & $0-0.50$ & 3.70 & 14 \\
$\mathrm{ZnO}_{1-x} \mathrm{Se}_{x}$ & $0-0.13$ & 8.00 & 14 \\
\hline \hline
\end{tabular}

${ }^{\mathrm{a}}$ Theoretical work.

the $\delta$ parameter. This speculation satisfies the growth orientation along the $c$-axis, which is responsible for the spontaneous polarization in the $\mathrm{Mg}_{x} \mathrm{Zn}_{1-x} \mathrm{O} / \mathrm{SiC}$ heterointerfaces. Therefore, the alloy polarization can be expressed as a composition-weighted Vegard-like average as $P_{\mathrm{Mg}_{\mathrm{x}} \mathrm{Zn}_{1-x} \mathrm{O}}^{\mathrm{SP}}(x)$ $=x P_{\mathrm{MgO}}^{\mathrm{SP}}+(1-x) P_{\mathrm{ZnO}}^{\mathrm{SP}}$. The $\delta$ due to the polarization $(P)$, therefore, can be described by ${ }^{11}$

$$
\delta_{\mathrm{Mg}_{x} \mathrm{Zn}_{1-x} \mathrm{O}}=2 P_{\mathrm{MgO}}+2 P_{\mathrm{ZnO}}-4 P_{\mathrm{Mg}_{0.5} \mathrm{Zn}_{0.5} \mathrm{O}} .
$$

It is noted that the spontaneous polarization for the $\mathrm{ZnO}$ and $\mathrm{MgO}$ materials has been reported to be -0.050 and $-0.070 \mathrm{C} / \mathrm{m}^{2}$, respectively. ${ }^{9}$ Substituting these values in Eq. (2), the spontaneous polarization for the $\mathrm{Mg}_{0.5} \mathrm{Zn}_{0.5} \mathrm{O}$ alloys has been estimated to be $-0.054 \mathrm{C} / \mathrm{m}^{2}$. This value is comparable with the binary $\mathrm{ZnO}$ and $\mathrm{MgO}$ compounds. It is also expected that this spontaneous polarization in the $\mathrm{Mg}_{x} \mathrm{Zn}_{1-x} \mathrm{O} / \mathrm{SiC}$ heterointerface plays an additional role in the negative bandgap bowing. ${ }^{12}$ However, for a clearer understanding on this issue, further studies are necessary. Table I shows the $\delta$ values for the particular II-O alloys. ${ }^{8,13,14}$

\section{CONCLUSION}

The localized exciton energy of $\mathrm{Mg}_{x} \mathrm{Zn}_{1-x} \mathrm{O}$ alloys deposited on $6 \mathrm{H}$-SiC substrates has been blueshifted in the range 212-248 meV, while the Stokes shift was $\sim 30 \mathrm{meV}$. The large bandgap bowing has been estimated in $\mathrm{Mg}_{x} \mathrm{Zn}_{1-x} \mathrm{O} / \mathrm{SiC}$ heterostructure to be $-4.72 \pm 0.84 \mathrm{eV}$. This large negative bowing, together with the large Stokes shift, has been attributed to the existence of spontaneous polarization $\left(-0.054 \mathrm{C} / \mathrm{m}^{2}\right)$ due to the polar growth of $\mathrm{Mg}_{x} \mathrm{Zn}_{1-x} \mathrm{O} / \mathrm{SiC}$ heterostructure and compositional inhomo- geneity locally. These results will contribute to settle down the long standing bandgap bowing nature in the $(\mathrm{Mg}, \mathrm{Zn}$, Cd)O matrix.

\section{ACKNOWLEDGMENTS}

This work is supported by the Australian Research Council.

${ }^{1}$ U. Ozgur, Y. I. Alivov, V. Liu, M. A. Reshchikov, S. Do, V. Avrutin, S.-J. Cho, and H. Morkoc, J. Appl. Phys. 98, 041301 (2005); A. Ashrafi and C. Jagadish, ibid. 102, 071101 (2007).

${ }^{2}$ S. J. Pearton, D. P. Norton, K. Ip, Y. W. Heo, and T. Steiner, Prog. Mater. Sci. 50, 293 (2005); A. Ashrafi and Y. Segawa, J. Appl. Phys. 103, 093527 (2008); A. B. M. A. Ashrafi, Y. Segawa, K. Shin, and T. Yao, Phys. Rev. B 72, 155302 (2005).

${ }^{3}$ J. F. Sarver, F. L. Katnack, and F. A. Hummel, J. Electrochem. Soc. 106, 960 (1959); S. F. Chichibu, A. Uedono, T. Onuma, B. A. Haskell, A. Chakraborty, T. Koyama, P. T. Fini, S. Keller, S. P. Denbars, J. S. Speck, U. K. Mishra, S. Nakamura, S. Yamaguchi, S. Kamiyama, H. Amano, I. Akasaki, J. Han, and T. Sota, Nature Mater. 5, 810 (2006).

${ }^{4}$ A. B. M. A. Ashrafi and Y. Segawa, J. Vac. Sci. Technol. B 23, 2030 (2005).

${ }^{5}$ A. F. Wright and J. S. Nelson, Appl. Phys. Lett. 66, 3051 (1995).

${ }^{6}$ A. B. M. A. Ashrafi, B.-P. Zhang, N. T. Binh, K. Wakatsuki, and Y. Segawa, Jpn. J. Appl. Phys., Part 1 43, 1114 (2004); A. B. M. A. Ashrafi, N. T. Binh, B.-P. Zhang, and Y. Segawa, Appl. Phys. Lett. 84, 2814 (2004); A. B. M. A. Ashrafi and Y. Segawa, Appl. Surf. Sci. 249, 139 (2005).

${ }^{7}$ F. K. Shan, B. I. Kim, G. X. Liu, Z. F. Liu, J. Y. Sohn, W. J. Lee, B. C. Shin, and Y. S. Yu, J. Appl. Phys. 95, 4772 (2004).

${ }^{8}$ (a) A. Ohtomo, M. Kawasaki, T. Koida, K. Masubuchi, H. Koinuma, Y. Sakurai, Y. Yoshida, T. Yasuda, and Y. Segawa, Appl. Phys. Lett. 72, 2466 (1998); (b) W. R. L. Lambrecht, S. Limpijumnong, and B. Segal, Theoretical Studies of $\mathrm{ZnO}$ and Related $\mathrm{MgZnO}$ Alloy Band Structures (The Office of Naval Research, Washington, DC, 2005); (c) S. F. Chichibu, A. Tsukazaki, M. Kawasaki, K. Tamura, Y. Segawa, T. Sota, and H. Koinuma, Appl. Phys. Lett. 80, 2860 (2002); (d) Y. Z. Zhu, G. D. Chen, H. Ye, A. Walsh, C. Y. Moon, and S.-H. Wei, Phys. Rev. B 77, 245209 (2008)

${ }^{9}$ J. Wu, W. Walukiewicz, K. M. Yu, J. W. Ager III, E. E. Haller, H. Lu, and W. J. Schaff, Appl. Phys. Lett. 80, 4741 (2002); S.-H. Park and D. Ahn, ibid. 87, 253509 (2005).

${ }^{10}$ L. H. Robins, J. T. Armstrong, R. B. Marinenko, M. D. Vaudin, C. E. Boudlin, J. C. Woicik, A. J. Paul, W. R. Thurber, K. E. Miyano, C. A. Parker, J. C. Roberts, S. M. Bedair, E. L. Piner, M. J. Reed, N. A. Elmasry, S. M. Donovan, and S. J. Pearton, IEEE International Symposium on Compound Semiconductors, Monterey, CA, 2000, p. 507.

${ }^{11}$ F. Bernardini and V. Fiorentini, Phys. Rev. B 64, 085207 (2001).

${ }^{12}$ T. Makino, Y. Segawa, M. Kawasaki, A. Ohtomo, R. Shiroki, K. Tamura, T. Yasuda, and H. Koinuma, Appl. Phys. Lett. 78, 1237 (2001).

${ }^{13}$ (a) S. F. Ding, G. H. Fan, S. T. Li, K. Chen, and B. Xiao, Physica B 394, 127 (2007); (b) T. Gruber, C. Kirchner, R. Kling, F. Reuss, A. Wagg, F. Bertram, D. Forster, J. Christen, and M. Schreck, Appl. Phys. Lett. 83, 3290 (2003).

${ }^{14}$ (a) N. Fathy and M. Ichimura, Jpn. J. Appl. Phys., Part 2 44, L1295 (2005); (b) Y. Nabetani, T. Mukawa, Y. Ito, T. Kato, and T. Matsumoto, Appl. Phys. Lett. 83, 1148 (2003). 